\title{
Characterization and classification of soils from an Amazonic Biome in western Pará
}

\begin{abstract}
Adão Pires Almada ${ }^{1} \odot$, Carlos Roberto Pinheiro Junior ${ }^{2} \odot$, Marcos Gervasio Pereira ${ }^{2 *}\left(\mathbb{0}\right.$, lolanda Maria Soares Reis $^{1} \odot$, Mateus Alves de Sousa ${ }^{1} \odot$, Luiz Alberto da Silva Rodrigues Pinto ${ }^{\circledR}$, Otávio Augusto Queiroz dos Santos ${ }^{\circledR}$

\footnotetext{
1 Universidade Federal do Oeste do Pará, Santarém, PA, Brasil. E-mail: adaoalmada1000@hotmail.com; iolandareis@outllok.com; mateussica@gmail.com

${ }^{2}$ Universidade Federal Rural do Rio de Janeiro, Seropédica, RJ, Brasil. E-mail: robertojrpinheiro@gmail.com; mgervasiopereira@gmail.com; I_arodrigues@yahoo.com.br; otavioqueiroz7@hotmail.com
}

ABSTRACT: Despite its great soil diversity, the Amazon Biome still lacks pedological studies that would also contributes to the Brazilian Soil Classification System. Based on this, this study aimed to characterize and classify the soils from an area in western Pará state. Six soil profiles were described and collected, characterized both physically and chemically, and then classified according to the Brazilian Soil Classification System. There were soils with anthropic influence with thick superficial horizons, with high levels of organic carbon, $\mathrm{Ca}^{2+}, \mathrm{Mg}^{2+}$ and $\mathrm{P}$, differing from the observed pattern concerning non-anthropized soils. A great variability of texture was also observed due to the nature of parental material. A high weathering degree was found in the Entisols located in the floodplain area, with low activity clays and low base saturation. Due to observing a superficial diagnostic anthropic horizon A in "Cambissolos Háplicos" and "Húmicos" profiles, it is suggested to create the "antrópico" (anthropic) subgroup for these soil classes in the Brazilian Soil Classification System.

\section{Caracterização e classificação de solos no Bioma amazônico no oeste do estado do Pará}

RESUMO: O Bioma Amazônico apesar da sua grande diversidade de solos ainda apresenta carência de estudos pedológicos, que contribuam para o Sistema Brasileiro de Classificação de Solo. A partir do exposto, o objetivo desse estudo foi caracterizar e classificar os solos de uma área no oeste do estado do Pará. Foram descritos e coletados seis perfis de solo, sendo esses caracterizados física e quimicamente e classificados segundo o Sistema Brasileiro de Classificação do Solo. Verificou-se solos com influência antrópica com horizontes superficiais espessos, com elevados teores de carbono orgânico, $\mathrm{Ca}^{2+}, \mathrm{Mg}^{2+}$ e $\mathrm{P}$, diferindo do padrão observado para solos não antropizados. Nos solos estudados foi observada uma grande variabilidade da textura decorrente da natureza do material de origem. Nos Gleissolos localizados na área de várzea verificou-se um elevado grau de intemperização, com argilas de baixa atividade e baixa saturação por bases. Devido a observação de horizonte diagnóstico superficial A antrópico em perfis de Cambissolos Háplicos e Húmicos, sugere-se a criação do subgrupo "antrópicos" para essas classes de solos no Sistema Brasileiro de Classificação de Solos.

Palavras-chave: Amazônia; antrópico; pedologia

\footnotetext{
* Marcos Gervasio Pereira - E-mail: mgervasiopereira@gmail.com (Corresponding author)

Associate Editor: Clístenes Williams Araújo Nascimento
} 


\section{Introduction}

Covering an extensive area with its high geological, geomorphological, edaphoclimatic and vegetation diversities, the Amazon rainforest also has its morphogenesis and pedogenesis directly related to the evolution of these mentioned factors (Vale Júnior et al., 2011). Among the several factors that mainly contribute in forming the climate of this environment, the equatorial climate stands out with its high temperatures and precipitation that can exceed over 3000 millimeters. Climatic conditions intensify the parent material weathering and here contribute to the formation of highly weathered soils overall, showing both high acidity and low cation exchange capacity (Freitas et al., 2013).

Even though there are soils with low natural fertility, some discontinuous patches of anthropic soils of high natural fertility are distributed throughout the Amazon territory, having high contents of $\mathrm{P}, \mathrm{Ca}^{2+}, \mathrm{Mg}^{2+}$, stabilized organic matter and high biological activity, (Santos et al., 2018a; Batistão et al., 2020). These soils are mainly associated with the "Argissolos" (Oxisols) and "Latossolos" (Ultisols) classes in the Brazilian Soil Classification System (BSCS) .

In the Amazonian environment, the large territorial extension contributes to the difficulty in reaching many areas, thus hindering the advancement of knowledge about soils in this region (Sousa et al., 2018a). Soil surveys conducted in the region are in a small scale that does not allow the more detailed planning of agricultural and forestry activities, settlement areas, irrigation and drainage project, among others (Araújo Filho et al., 2013). Due to this, agricultural use in some areas has caused negative impacts, reducing the organic carbon content, the soil microbial activity and total porosity (Silva Junior et al., 2012; Aquino et al., 2014; Farias et al., 2016; Zenero et al., 2016).

Pedological studies, in addition to a better understanding of the soil genesis in the Amazon region, contribute to the improvement of the Brazilian Soil Classification System -
SiBCS (Santos et al., 2018b). Although some studies on the characterization and classification of soils in the Amazon region have been conducted in distinct environments, such as floodplain areas (Guimarães et al., 2013), Archaeological Black Earths (Batistão et al., 2020) and areas of agricultural and forest production (Zenero et al., 2016), the demand for studies of this nature in the Amazonian environment is still high.

Given this context, the objective of this study was to characterize and classify some soil profiles located in the western Pará state in order to expand the pedological knowledge and contribute to the improvement of the Brazilian System of Soil Classification.

\section{Materials and Methods}

Located in the municipality of Santarém, western Pará state (Figure 1), the studied area has as its primary vegetation a predominantly Subperennial Tropical Rainforest and a humid tropical climate (Am according to Köppen), with annual rainfall

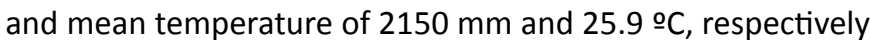
(Fisch et al., 1998).

Overall, the geology of the region is composed of sandstones, pelites, and conglomerates of the Alter-do-Chão Formation (Mendes et al., 2012), and the main relief features are inserted in the geomorphological units of the Tapajós Plateau - Xingu and the Patamares de Tapajós. In the area of the Tapajós Plateau - Xingu, the tabular areas are represented as high plateaus with erosive edges of low slope, which join the dissected relief of the Lowered Plateau. There is also smaller relief forms within the tabular ranges, consisting of low and medium dissected or flattened hills (IBGE, 2008).

For the study, six points were selected for the opening trenches, all located in the Experimental Unit from the Campus of the Federal University of Western Pará and in the Tapajós National Forest (Flona). The profiles were chosen in order to

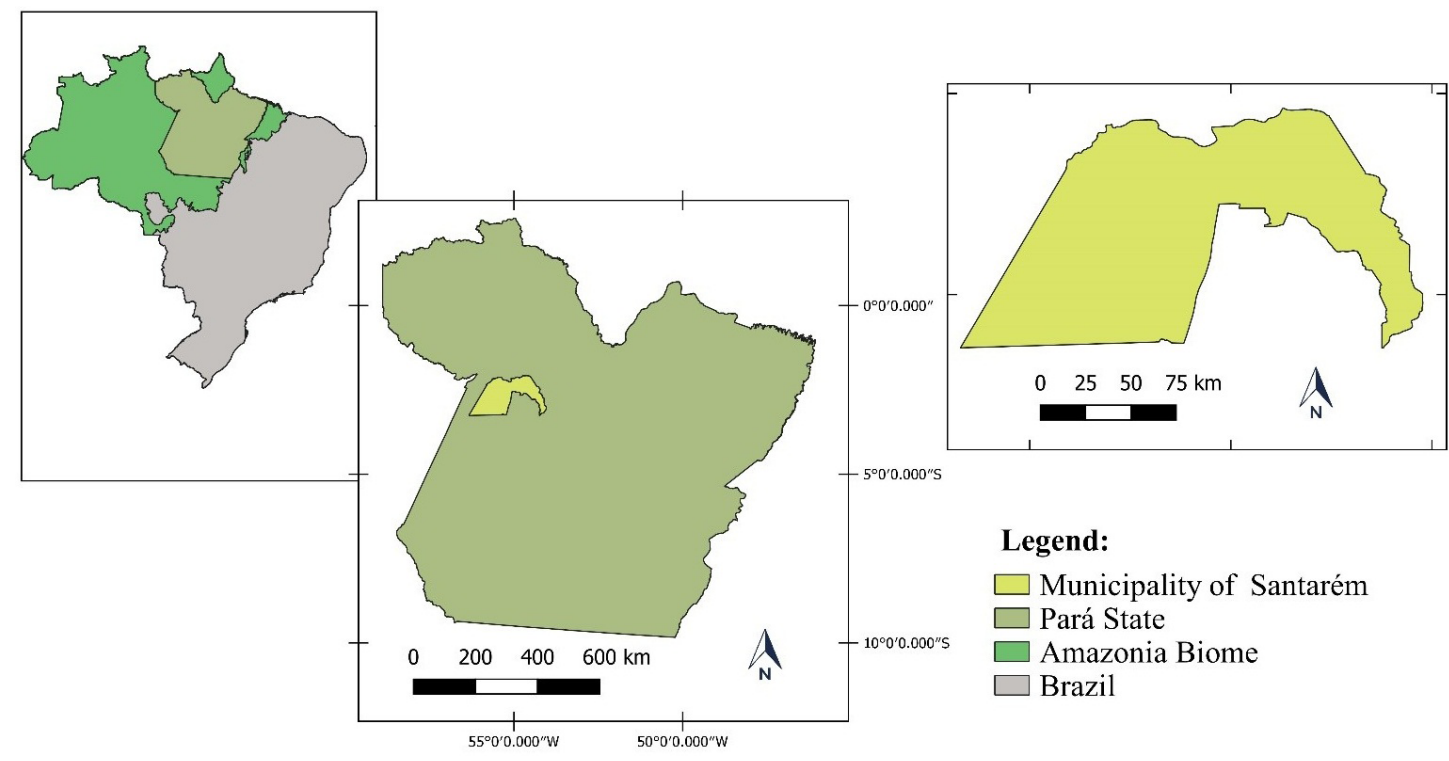

Figure 1. Map of the studied area. 
Table 1. General information of the profiles collected in western Pará state.

\begin{tabular}{|c|c|c|c|}
\hline Profile & Coordinates/Elevation & Drainage & Current use - Place \\
\hline P1 & $\begin{array}{c}02^{\circ} 41^{\prime} 08.1^{\prime \prime} \mathrm{S} 54^{\circ} 32^{\prime} 17.7^{\prime \prime} \mathrm{W} \\
69 \mathrm{~m}\end{array}$ & Poorly drained & Grass understory - UFOPA Experimental Farm \\
\hline P2 & $\begin{array}{c}02^{\circ} 41^{\prime} 10.9^{\prime \prime} \mathrm{S} 54^{\circ} 32^{\prime} 13.9^{\prime \prime} \mathrm{W} \\
72 \mathrm{~m}\end{array}$ & Well drained & Reforestation ( 4 years) - UFOPA Experimental Farm \\
\hline P3 & $\begin{array}{c}02^{\circ} 41^{\prime} 06.3^{\prime \prime} \mathrm{S} 54^{\circ} 31^{\prime} 55.2^{\prime \prime} \mathrm{W} \\
78 \mathrm{~m}\end{array}$ & Well drained & Secondary forest under regeneration - UFOPA Experimental Farm \\
\hline P4 & $\begin{array}{c}02^{\circ} 40^{\prime} 08.7^{\prime \prime} \mathrm{S} 54^{\circ} 31^{\prime} 21.3^{\prime \prime} \mathrm{W} \\
149 \mathrm{~m}\end{array}$ & Well drained & Secondary dense forest (legal reserve) - UFOPA Experimental Farm \\
\hline P5 & $\begin{array}{c}2^{\circ} 25^{\prime} 10.3^{\prime \prime} \mathrm{S} 54^{\circ} 44^{\prime} 22.0^{\prime \prime} \mathrm{W} \\
23 \mathrm{~m}\end{array}$ & Well drained & Secondary forest under regeneration - Tapajós Unit - UFOPA \\
\hline P6 & $\begin{array}{c}2^{\circ} 25^{\prime} 10.5^{\prime \prime} \mathrm{S} 54^{\circ} 44^{\prime} 20.8^{\prime \prime} \mathrm{W} \\
22 \mathrm{~m}\end{array}$ & Well drained & Secondary forest under regeneration - Tapajós Unit UFOPA \\
\hline
\end{tabular}

contemplate the environmental variations of the region, five on land and one in the floodplains. General information on the collection points is displayed in Table 1.

Morphological description of the profiles and collection of deformed samples from the horizons were according as the described by Santos et al. (2015). Samples were placed on a bench for air-drying, then crushed afterwards and passed through sieves with aperture mesh of $2.0 \mathrm{~mm}$, obtaining the air-dried fine soil fraction (AFSF), from which the physical and chemical analyses were performed.

Particle size analysis was performed by using the pipette method (Teixeira et al., 2017), thus quantifying the sand, silt and clay contents. Chemical analyses, performed according to Teixeira et al. (2017), determined the following: (a) pH values in water and in $\mathrm{KCl} 1 \mathrm{~mol} \mathrm{~L}^{-1}$; (b) $\mathrm{Ca}^{2+}, \mathrm{Mg}^{2+}$ and $\mathrm{Al}^{3+}$, extracted with $\mathrm{KCl} 1 \mathrm{~mol} \mathrm{~L}^{-1}$ solution, with $\mathrm{Ca}^{2+}$ and $\mathrm{Mg}^{2+}$ quantified by complexometry using EDTA solution and $\mathrm{Al}^{3+}$ by titrimetry using $\mathrm{NaOH}$ solution; c) $\mathrm{Na}^{+}, \mathrm{K}^{+}$and $\mathrm{P}$, extracted with a double acid solution $\left(\mathrm{HCl}+\mathrm{H}_{2} \mathrm{SO}_{4}\right)$, with $\mathrm{Na}^{+}$and $\mathrm{K}^{+}$determined by flame photometer and $\mathrm{P}$ quantified by spectrometry, based on the color development of the phosphomolybide complex; d) $\mathrm{H}^{+} \mathrm{Al}$, determination with a calcium acetate solution and quantified by titrimetry by using $\mathrm{NaOH}$ solution in presence of phenolphthalein.

Quantification of total organic carbon content was according to Yeomans \& Brenmer (1988), with potassium dichromate as an oxidizing agent in an acid medium, titrating the excess with ferrous ammoniacal sulfate solution.

$\mathrm{Fe}_{2} \mathrm{O}_{3}$ and $\mathrm{Al}_{2} \mathrm{O}_{3}$ contents were determined by sulfuric attack and $\mathrm{SiO}_{2}$ by subsequent alkaline dissolution (Teixeira et al., 2017), in which TFSA samples were dissolved in $\mathrm{H}_{2} \mathrm{SO}_{4}$ $1: 1$, heated and then passed through a filter (Whatman no. 40). From the filtered extract, $\mathrm{Fe}_{2} \mathrm{O}_{3}$ and $\mathrm{Al}_{2} \mathrm{O}_{3}$ were quantified by complexometry with EDTA and CDTA, respectively, and, with the $\mathrm{SiO}_{2}$ content obtained from the solubilization of the residue in $\mathrm{NaOH}$ and quantified by colorimetry from the color intensity of the silico-molybdic complex. From the results obtained, the $\mathrm{ki}$ and $\mathrm{kr}$ indexes and the ratio $\mathrm{Al}_{2} \mathrm{O}_{3} / \mathrm{Fe}_{2} \mathrm{O}_{3}$ were then calculated.

Based on the morphological, physical and chemical attributes, the profiles were finally classified according to the Brazilian Soil Classification System (Santos et al., 2018b).

\section{Results and Discussion}

Tables 2 and 3 displays the main results of the chemical and physical attributes of the profiles studied. Overall, there was great variability in the studied soils attributes, mainly due to the evidence of anthropic activity seen in profiles P3, P5 and P6, such as ceramic fragments and remains of bones, responsible for both morphological changes in color and structure, as well as the chemical changes, such as levels of $\mathrm{Ca}^{2+}, \mathrm{Mg}^{2+}, \mathrm{P}$ and TOC.

The effective depth of studied soils ranged from 103 to $206 \mathrm{~cm}$, thus placing then within the deep or very deep classes (Table 2) (IBGE, 2015). Yet the superficial horizons of the profiles, where the anthropic activities were evidenced, are thicker (ranging from 53 to $60 \mathrm{~cm}$ ) and of darker colors when compared to the others. This pattern, of thicker and darker horizons, is directly related to the enrichment of organic carbon by pre-Columbian communities (Bastidão et al., 2020). In general, the colors were darker in the surface horizons and more chromatic in the subsurface, with the predominance of yellowish hues (10YR), which is directly related to the low $\mathrm{Fe}_{2} \mathrm{O}_{3}$ content of the sulfuric attack (Table 4) (Meireles et al., 2012). This condition associates with a more humid environment, with the low iron content in the source material and with the organic carbon content, favoring the goethite formation. In the floodplain environment (P1), due to the restricted drainage condition, intensifying hydromorphic processes and consequent reduction and iron removal (Guimarães et al., 2013), greenish-gray colors (5GY) were observed; in addition, this drainage restriction favors the organic matter accumulation, which explains the horizon with thick surface and very dark colors.

As for the structure (Table 2), the granular type is present in both the superficial horizons and subangular blocks in the subsurface, with its size ranging from small to medium. However, in profiles P3 and P4, the angular type blocks were even in the surface horizons, which may be associated with a more clayey texture and a greater occurrence of wetting and drying cycles that favor the formation of this aggregate type (Kämpf \& Curi, 2012). A structure with a strong development degree was found in all horizons with evidence of anthropic 
Table 2. Morphological attributes and granulometry of soils under Amazonian environment in western Pará state.

\begin{tabular}{|c|c|c|c|c|c|c|c|c|c|}
\hline \multirow{2}{*}{ Hor } & \multirow{2}{*}{$\begin{array}{c}\text { Depth } \\
(\mathrm{cm}) \\
\end{array}$} & \multirow{2}{*}{$\begin{array}{l}\text { Color } \\
\text { wet }\end{array}$} & \multirow{2}{*}{ Structure } & \multirow{2}{*}{$\begin{array}{c}\text { Textural } \\
\text { class }\end{array}$} & Sand & Silt & Clay & \multirow{2}{*}{$\begin{array}{l}\text { Silt } \\
\text { clay }\end{array}$} & \multirow{2}{*}{$\begin{array}{c}\text { CEE } \\
\left(\mathrm{cmol}_{\mathrm{c}} \mathrm{kg}^{-1}\right)\end{array}$} \\
\hline & & & & & \multicolumn{3}{|c|}{$\left(\mathrm{g} \mathrm{kg}^{-1}\right)$} & & \\
\hline \multicolumn{10}{|c|}{ Profile 1 - Gleissolo Melânicos Tb Distrófico cambissólico(Entisol) } \\
\hline A & $0-48$ & 5 GY $3 / 1$ & mo, bsa, me & FAA & 574 & 88 & 338 & 0.3 & - \\
\hline $\mathrm{Bg}$ & $42-103^{+}$ & $5 \mathrm{GY} 7 / 1$ & mo, bsa, me & AA & 447 & 152 & 401 & 0.4 & 9.5 \\
\hline \multicolumn{10}{|c|}{ Profile 2 - Latossolo Amarelo Distrófico argissólico(Oxisol) } \\
\hline$A$ & $0-10$ & 10 YR $3 / 3$ & mo, gr, pe & FAA & 679 & 87 & 234 & 0.4 & - \\
\hline$A B$ & $10-21$ & 10 YR 4/3 & fo, gr, me & FAA & 589 & 86 & 325 & 0.3 & - \\
\hline BA & $21-39$ & 10 YR 4/4 & mo, gr, me & $A A$ & 500 & 90 & 410 & 0.2 & 11.1 \\
\hline Bw1 & $39-68$ & 10 YR 6/6 & mo, bsa, me & $A$ & 426 & 99 & 475 & 0.2 & 8.5 \\
\hline Bw2 & $68-86$ & 10 YR $6 / 6$ & mo, bsa, me & A & 439 & 82 & 479 & 0.2 & 6.2 \\
\hline Bw3 & $86-138$ & 10 YR $7 / 8$ & mo, bsa, me & $A$ & 440 & 92 & 468 & 0.2 & 6.7 \\
\hline Bw4 & $138-204^{+}$ & 10 YR $7 / 8$ & mo, bsa, me & $A A$ & 474 & 64 & 462 & 0.1 & 6.8 \\
\hline \multicolumn{10}{|c|}{ Profile 3 - Latossolo Amarelo Distrófico antrópico (Oxisol) } \\
\hline Au1 & $0-10$ & 10 YR $2 / 1$ & fo, bsa, pq & A & 137 & 273 & 590 & 0.5 & - \\
\hline Au2 & $10-20$ & 10 YR $2 / 2$ & fo, bsa, pq & MA & 137 & 235 & 628 & 0.4 & - \\
\hline Au3 & $20-36$ & 10 YR $3 / 2$ & mo, bsa, pq & MA & 144 & 229 & 627 & 0.4 & - \\
\hline$A B$ & $36-53$ & 10 YR $3 / 3$ & mo, bsa, me & MA & 105 & 216 & 679 & 0.3 & - \\
\hline $\mathrm{BA}$ & $53-94$ & 10 YR 5/6 & mo, bsa, me & MA & 61 & 196 & 743 & 0.3 & 11.3 \\
\hline Bw1 & $94-135$ & 10 YR $7 / 6$ & fo, bsa, me & MA & 41 & 252 & 707 & 0.4 & 9.3 \\
\hline Bw2 & $135-206^{+}$ & 10 YR $7 / 6$ & fo, bsa, me & MA & 41 & 244 & 715 & 0.3 & 6.8 \\
\hline \multicolumn{10}{|c|}{ Profile 4 - Latossolo Amarelo Distrófico típico(Oxisol) } \\
\hline A & $0-19$ & 10 YR 4/4 & fo, bsa, pe & MA & 77 & 164 & 759 & 0.2 & - \\
\hline$A B$ & $19-35$ & 10 YR 4/6 & fo, bsa, pe & MA & 52 & 151 & 797 & 0.2 & - \\
\hline BA & $35-49$ & 10 YR $5 / 6$ & mo, bsa, pe & MA & 43 & 136 & 821 & 0.2 & 8.3 \\
\hline Bw1 & $49-62$ & 10 YR $6 / 8$ & mo, bsa, pe & MA & 37 & 100 & 863 & 0.1 & 7.2 \\
\hline Bw2 & $62-75$ & 10 YR $6 / 8$ & mo, bsa, me & $\mathrm{MA}$ & 29 & 78 & 893 & 0.1 & 6.1 \\
\hline Bw3 & $75-102$ & 10 YR $6 / 8$ & mo, bsa, me & MA & 42 & 70 & 888 & 0.1 & 5.7 \\
\hline Bw4 & $102-156$ & 10 YR 6/8 & fo, bsa, me & MA & 41 & 141 & 818 & 0.2 & 6.0 \\
\hline Bw5 & $156-203^{+}$ & 10 YR $7 / 8$ & fo, bsa, me & MA & 47 & 150 & 803 & 0.2 & 5.4 \\
\hline \multicolumn{10}{|c|}{ Profile 5 - Cambissolo Háplico Tb Distrófico latossólico antrópico(Cambisol) } \\
\hline Au1 & $0-10$ & $10 \mathrm{YR} 2 / 2$ & mo, gr, pe & FA & 782 & 67 & 151 & 0.4 & - \\
\hline Au2 & $10-24$ & 10 YR $2 / 2$ & mo, gr, pe & FA & 804 & 44 & 152 & 0.3 & - \\
\hline Au3 & $24-40$ & 10 YR $2 / 2$ & mo, gr, pe & FA & 762 & 61 & 177 & 0.3 & - \\
\hline$A B$ & $40-60$ & 10 YR 3/3 & mo, bsa, pe & $\mathrm{FA}$ & 742 & 79 & 179 & 0.4 & - \\
\hline BA & $60-84$ & 10 YR 4/4 & mo, bsa, pe & FAA & 737 & 61 & 202 & 0.3 & 22.6 \\
\hline $\mathrm{Bi1}$ & $84-103$ & 10 YR 5/6 & mo, bsa, pe & FAA & 737 & 44 & 219 & 0.2 & 19.0 \\
\hline $\mathrm{Bi} 2$ & $103-161$ & 10 YR $6 / 6$ & mo, bsa, pe & FAA & 737 & 51 & 212 & 0.2 & 18.6 \\
\hline $\mathrm{Bi3}$ & $161-202^{+}$ & 10 YR $6 / 6$ & mo, bsa, pe & FAA & 713 & 54 & 233 & 0.2 & 12.7 \\
\hline \multicolumn{10}{|c|}{ Profile 6 - Cambissolo Húmico Distrófico antrópico(Cambisol) } \\
\hline Au1 & $0-13$ & 10 YR $3 / 1$ & mo, gr, pe & FA & 742 & 92 & 166 & 0.6 & - \\
\hline Au2 & $13-26$ & 10 YR $3 / 2$ & mo, gr, pe & FAA & 721 & 84 & 195 & 0.4 & - \\
\hline Au3 & $26-40$ & 10 YR $3 / 3$ & mo, bsa, pe & FAA & 708 & 72 & 220 & 0.3 & - \\
\hline$A B$ & $40-55$ & 10 YR 4/4 & mo, bsa, pe & FAA & 750 & 44 & 206 & 0.2 & - \\
\hline Bi1 & $55-77$ & 10 YR 4/6 & mo, bsa, pe & FAA & 723 & 44 & 233 & 0.2 & 22.1 \\
\hline $\mathrm{Bi} 2$ & $77-103^{+}$ & 10 YR 5/6 & mo, bsa, pe & FAA & 737 & 28 & 235 & 0.1 & 19.8 \\
\hline
\end{tabular}

Legend: Hor = horizon; $\mathrm{mo}=$ moderate; fo = strong; gr = granular; bsa = subangular blocks; pe = small; $m e=$ medium; $F A=$ sandy loam; $F A A=$ sandy clay loam; $A A=$ sandy clay; $A=$ clay; $\mathrm{MA}=$ very clayey; $\mathrm{CEE}=\left(\left(\mathrm{T}^{*} 1000\right) /\right.$ clay content $)$.

activity, which is directly related to the addition of organic matter (Rabot et al., 2018).

There was great variability in the particle size among studied profiles, ranging from sandy loam to very clayey. This grain size pattern is directly related to geological aspects, considering that the Alter do Chão Formation is characterized by the occurrence of sedimentary rocks of clastic nature with a varied grain size, having sandstones, argillites and conglomerates (Mendes et al., 2012); despite this, particle size distribution within the profiles is more homogeneous, with small variations in depth. In profiles P3 and P4 the very clayey class was predominant, with clay content reaching up to $893 \mathrm{~g} \mathrm{~kg}^{-1}$, while in P1, P5 and P6, the sandy loam and sandy clay loam classes predominated, with clay content averaging roughly $200 \mathrm{~g} \mathrm{~kg}^{-1}$. In profile 2 , there was an increased clay content at depth, ranging from 234 (A) to $479 \mathrm{~g} \mathrm{~kg}^{-1}$ (Bw2); however, this increment was insufficient to characterize the textural gradient (Santos et al., 2018b). P3 and P4 were where the highest silt contents were, reaching up to $273 \mathrm{~g} \mathrm{~kg}^{-1}$, albeit values of the silt/clay ratio were very low in all profiles, ranging from 0.1 to 0.6 . Furthermore, all profiles have low activity clay (Santos et al., 2018b), less than $10 \mathrm{cmolc} \mathrm{kg}^{-1}$ of clay, in almost 
Table 3. Chemical attributes of soils under Amazonian environment in western Pará state.

\begin{tabular}{|c|c|c|c|c|c|c|c|c|c|c|c|c|c|c|}
\hline \multirow{2}{*}{ Hor } & \multicolumn{2}{|c|}{$\mathrm{pH}$} & \multirow{2}{*}{$\Delta \mathrm{pH}$} & $\mathrm{Ca}^{2+}$ & $\mathrm{Mg}^{2+}$ & $\mathrm{Al}^{3+}$ & $\mathbf{K}^{+}$ & $\mathrm{Na}^{+}$ & $\mathrm{H}+\mathrm{Al}$ & $\mathbf{S}$ & $\mathbf{T}$ & \multirow{2}{*}{$\begin{array}{c}V \\
(\%)\end{array}$} & \multirow{2}{*}{$\begin{array}{c}\mathrm{P} \\
\left(\mathrm{mg} \mathrm{kg}^{-1}\right)\end{array}$} & \multirow{2}{*}{$\begin{array}{c}\text { TOC } \\
\left(\mathrm{g} \mathrm{kg}^{-1}\right)\end{array}$} \\
\hline & $\mathrm{H}_{2} \mathrm{O}$ & $\mathrm{KCl}$ & & \multicolumn{8}{|c|}{$\left(\mathrm{cmol}_{\mathrm{c}} \mathrm{kg}^{-1}\right)$} & & & \\
\hline \multicolumn{15}{|c|}{ Profile 1 - Gleissolo Melânicos Tb Distrófico cambissólico(Entisol) } \\
\hline A & 4.51 & 3.84 & -0.67 & 0.2 & 0.4 & 2.3 & 0.05 & 0.06 & 8.6 & 0.71 & 9.31 & 7 & 6 & 23 \\
\hline $\mathrm{Bg}$ & 4.33 & 4.08 & -0.25 & 0.2 & 0.4 & 2.8 & 0.03 & 0.04 & 3.1 & 0.67 & 3.77 & 17 & 3 & 6 \\
\hline \multicolumn{15}{|c|}{ Profile 2 - Latossolo Amarelo Distrófico argissólico (Oxisol) } \\
\hline A & 5.47 & 3.83 & -1.64 & 0.5 & 0.3 & 0.4 & 0.04 & 0.04 & 6.3 & 0.88 & 7.18 & 12 & 3 & 14 \\
\hline$A B$ & 5.34 & 3.91 & -1.43 & 0.3 & 0.2 & 0.6 & 0.03 & 0.04 & 5.5 & 0.57 & 6.07 & 9 & 2 & 11 \\
\hline $\mathrm{BA}$ & 5.42 & 4.02 & -1.40 & 0.5 & 0.2 & 0.5 & 0.03 & 0.03 & 3.8 & 0.76 & 4.56 & 17 & 3 & 8 \\
\hline Bw1 & 5.29 & 4.06 & -1.23 & 0.6 & 0.1 & 0.5 & 0.03 & 0.04 & 3.3 & 0.77 & 4.07 & 19 & 2 & 6 \\
\hline Bw2 & 5.32 & 4.06 & -1.26 & 0.4 & 0.2 & 0.4 & 0.03 & 0.03 & 3.3 & 0.66 & 3.96 & 22 & 2 & 6 \\
\hline Bw3 & 5.32 & 4.08 & -1.24 & 0.3 & 0.4 & 1.2 & 0.03 & 0.03 & 2.5 & 0.76 & 3.26 & 21 & 2 & 3 \\
\hline Bw4 & 5.38 & 4.17 & -1.21 & 0.3 & 0.3 & 1.8 & 0.03 & 0.03 & 2.5 & 0.66 & 3.16 & 21 & 3 & 3 \\
\hline \multicolumn{15}{|c|}{ Profile 3 - Latossolo Amarelo Distrófico antrópico (Oxisol) } \\
\hline Au1 & 6.20 & 5.07 & -1.13 & 8.4 & 3.3 & 0.0 & 0.10 & 0.05 & 9.9 & 11.85 & 21.75 & 54 & 102 & 42 \\
\hline Au2 & 6.34 & 5.17 & -1.17 & 8.3 & 2.4 & 0.0 & 0.04 & 0.05 & 8.6 & 10.79 & 19.39 & 56 & 138 & 30 \\
\hline Au3 & 6.39 & 5.13 & -1.26 & 6.3 & 2.4 & 0.0 & 0.03 & 0.05 & 7.9 & 8.78 & 16.68 & 53 & 136 & 25 \\
\hline$A B$ & 6.31 & 5.07 & -1.24 & 5.0 & 1.5 & 0.0 & 0.03 & 0.04 & 7.4 & 6.57 & 13.97 & 47 & 138 & 16 \\
\hline BA & 6.31 & 5.19 & -1.12 & 2.9 & 1.1 & 0.0 & 0.02 & 0.03 & 4.5 & 4.05 & 8.55 & 47 & 118 & 8 \\
\hline Bw1 & 6.29 & 5.52 & -0.77 & 2.0 & 0.9 & 0.0 & 0.02 & 0.03 & 3.6 & 2.95 & 6.55 & 45 & 140 & 9 \\
\hline Bw2 & 6.17 & 5.62 & -0.55 & 1.8 & 0.5 & 0.0 & 0.02 & 0.03 & 2.6 & 2.35 & 4.95 & 46 & 229 & 4 \\
\hline \multicolumn{15}{|c|}{ Profile 4 - Latossolo Amarelo Distrófico típico(Oxisol) } \\
\hline A & 4.47 & 3.70 & -0.77 & 0.2 & 0.2 & 1.4 & 0.06 & 0.03 & 12.1 & 0.49 & 12.59 & 4 & 3 & 19 \\
\hline$A B$ & 4.81 & 3.84 & -0.97 & 0.2 & 0.2 & 1.2 & 0.03 & 0.03 & 8.1 & 0.46 & 8.56 & 5 & 2 & 15 \\
\hline $\mathrm{BA}$ & 4.80 & 3.91 & -0.89 & 0.1 & 0.2 & 1.1 & 0.03 & 0.03 & 6.4 & 0.36 & 6.76 & 5 & 2 & 11 \\
\hline Bw1 & 4.84 & 3.94 & -0.90 & 0.1 & 0.3 & 0.9 & 0.03 & 0.03 & 5.8 & 0.46 & 6.26 & 7 & 2 & 7 \\
\hline Bw2 & 4.88 & 3.97 & -0.91 & 0.1 & 0.2 & 0.8 & 0.02 & 0.03 & 5.1 & 0.35 & 5.45 & 6 & 2 & 6 \\
\hline Bw3 & 4.91 & 3.95 & -0.96 & 0.1 & 0.3 & 0.9 & 0.03 & 0.03 & 4.6 & 0.46 & 5.06 & 9 & 2 & 6 \\
\hline Bw4 & 5.00 & 3.98 & -1.02 & 0.1 & 0.3 & 0.9 & 0.02 & 0.03 & 4.5 & 0.45 & 4.95 & 9 & 2 & 5 \\
\hline Bw5 & 4.82 & 4.06 & -0.76 & 0.3 & 0.2 & 0.6 & 0.04 & 0.03 & 3.8 & 0.57 & 4.37 & 13 & 3 & 5 \\
\hline \multicolumn{15}{|c|}{ Profile 5 - Cambissolo Háplico Tb Distrófico latossólico antrópico(Cambisol) } \\
\hline Au1 & 6.06 & 5.01 & -1.05 & 3.7 & 1.3 & 0.0 & 0.06 & 0.04 & 8.3 & 5.10 & 13.40 & 38 & 355 & 16 \\
\hline Au2 & 5.69 & 4.32 & -1.37 & 1.5 & 0.8 & 0.0 & 0.04 & 0.03 & 6.9 & 2.37 & 9.27 & 25 & 211 & 13 \\
\hline Au3 & 5.36 & 3.98 & -1.38 & 0.7 & 0.7 & 0.4 & 0.03 & 0.03 & 8.9 & 1.46 & 10.36 & 13 & 173 & 13 \\
\hline$A B$ & 5.23 & 3.93 & -1.30 & 0.6 & 0.3 & 0.4 & 0.02 & 0.04 & 6.9 & 0.96 & 7.86 & 12 & 65 & 9 \\
\hline BA & 5.25 & 3.93 & -1.32 & 0.5 & 0.2 & 0.4 & 0.02 & 0.04 & 3.8 & 0.76 & 4.56 & 12 & 21 & 5 \\
\hline Bi1 & 5.41 & 4.07 & -1.34 & 0.5 & 0.3 & 0.3 & 0.02 & 0.05 & 3.3 & 0.87 & 4.17 & 14 & 16 & 5 \\
\hline $\mathrm{Bi} 2$ & 5.12 & 4.10 & -1.02 & 0.6 & 0.3 & 0.2 & 0.02 & 0.03 & 3.0 & 0.95 & 3.95 & 22 & 32 & 4 \\
\hline $\mathrm{Bi} 3$ & 5.10 & 4.11 & -0.99 & 0.2 & 0.5 & 0.2 & 0.03 & 0.03 & 2.2 & 0.76 & 2.96 & 26 & 18 & 3 \\
\hline \multicolumn{15}{|c|}{ Profile 6 - Cambissolo Húmico Distrófico antrópico(Cambisol) } \\
\hline Au1 & 6.08 & 4.70 & -1.38 & 4.5 & 0.9 & 0.0 & 0.04 & 0.04 & 7.4 & 5.48 & 12.88 & 42 & 422 & 23 \\
\hline Au2 & 5.87 & 4.76 & -1.11 & 6.6 & 1.2 & 0.0 & 0.04 & 0.04 & 8.4 & 7.88 & 16.28 & 48 & 178 & 19 \\
\hline Au3 & 6.01 & 4.83 & -1.18 & 6.7 & 1.1 & 0.0 & 0.03 & 0.04 & 8.1 & 7.87 & 15.97 & 49 & 78 & 30 \\
\hline$A B$ & 6.13 & 4.86 & -1.27 & 3.8 & 0.7 & 0.0 & 0.03 & 0.03 & 5.3 & 4.56 & 9.86 & 46 & 54 & 19 \\
\hline $\mathrm{Bi1}$ & 5.61 & 4.57 & -1.04 & 1.5 & 0.8 & 0.0 & 0.02 & 0.03 & 2.8 & 2.65 & 5.15 & 46 & 41 & 7 \\
\hline $\mathrm{Bi} 2$ & 5.65 & 4.60 & -1.05 & 1.1 & 1.0 & 0.0 & 0.03 & 0.03 & 2.5 & 2.16 & 4.66 & 46 & 48 & 5 \\
\hline
\end{tabular}

Legend: Hor $=$ horizon; $\mathrm{S}=$ sum of bases; $\mathrm{T}=\mathrm{S}+\mathrm{H}+\mathrm{Al} ; \mathrm{V} \%=(\mathrm{S} / \mathrm{T})^{* 100} ; \mathrm{TOC}=$ total organic carbon.

all horizons of profiles P1, P2, P3 and P4, while in P5 and P6

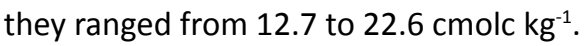

With concerns to the chemical attributes (Table 3), there was a pattern directly related to the influence of anthropic actions in almost all the studied elements. In profiles P3, P5 and P6, which have evidence of anthropic activities, such as ceramic fragments among other materials, the highest levels of $\mathrm{Ca}^{2+}$ and $\mathrm{Mg}^{2+}$ were observed, reaching levels of up to 8.4 and $3.3 \mathrm{cmolc} \mathrm{kg}^{-1}$, respectively (Table 3 ). This predominance of basic cations is the main responsible for the higher $\mathrm{pH}$ values in these profiles, close to 6.0 in almost all horizons, which explains the null values of $\mathrm{Al}^{3+}$, especially in P3 and P6. Differing from the patterns observed by Santos et al. (2013) and Santos et al. (2018a) in areas of Archaeological Black Earth, the $\mathrm{K}^{+}$ values were considered as very low in all studied soils, having a maximum content of $0.10 \mathrm{cmolc} \mathrm{kg}^{-1}$ in Au1 of P3.

Total organic carbon (TOC) is also directly related to anthropic influence observed in the superficial horizons of P3 and P6, with contents of 30 and $42 \mathrm{~g} \mathrm{~kg}^{-1}$, respectively. Despite the higher values of the sum of bases $(S)$ in these profiles, only the horizons Au1, Au2 and Au3 of P3 showed values of base saturation (V) higher than $50 \%$.

Phosphorus contents were very high in soils with the evidenced anthropic activity, including in the subsurface 
Table 4. Pedogenetical oxids and indexes $\mathrm{Ki}$ and $\mathrm{Kr}$ of soils under Amazonian environment in western Pará state.

\begin{tabular}{|c|c|c|c|c|c|c|}
\hline Hor & $\mathrm{SiO}_{2}$ & $\frac{\mathrm{Al}_{2} \mathrm{O}_{3}}{\left(\mathrm{~g} \mathrm{~kg}^{-1}\right)}$ & $\mathrm{Fe}_{2} \mathrm{O}_{3}$ & Ki & $\mathbf{K r}$ & $\mathrm{Al}_{2} \mathrm{O}_{3} / \mathrm{Fe}_{2} \mathrm{O}_{3}$ \\
\hline \multicolumn{7}{|c|}{ Profile 1 - Gleissolo Melânicos Tb Distrófico cambissólico(Entisol) } \\
\hline A & 176 & 158 & 3 & 1.9 & 1.9 & 82.7 \\
\hline $\mathrm{Bg}$ & 202 & 191 & 9 & 1.8 & 1.7 & 33.3 \\
\hline \multicolumn{7}{|c|}{ Profile 2 - Latossolo Amarelo Distrófico argissólico(Oxisol) } \\
\hline A & 114 & 116 & 4 & 1.7 & 1.6 & 45.5 \\
\hline$A B$ & 159 & 161 & 4 & 1.7 & 1.7 & 63.2 \\
\hline BA & 186 & 211 & 9 & 1.5 & 1.5 & 36.8 \\
\hline Bw1 & 183 & 282 & 7 & 1.1 & 1.1 & 63.2 \\
\hline Bw2 & 196 & 275 & 7 & 1.2 & 1.2 & 61.7 \\
\hline Bw3 & 198 & 259 & 10 & 1.3 & 1.3 & 40.7 \\
\hline Bw4 & 202 & 258 & 3 & 1.3 & 1.3 & 135.0 \\
\hline \multicolumn{7}{|c|}{ Profile 3 - Latossolo Amarelo Distrófico antrópico(Oxisol) } \\
\hline Au1 & 292 & 263 & 31 & 1.9 & 1.8 & 13.3 \\
\hline Au2 & 288 & 302 & 35 & 1.6 & 1.5 & 13.5 \\
\hline Au3 & 292 & 308 & 28 & 1.6 & 1.5 & 17.3 \\
\hline$A B$ & 316 & 329 & 34 & 1.6 & 1.5 & 15.2 \\
\hline BA & 346 & 363 & 31 & 1.6 & 1.5 & 18.4 \\
\hline Bw1 & 348 & 325 & 34 & 1.8 & 1.7 & 15.0 \\
\hline Bw2 & 348 & 325 & 39 & 1.8 & 1.7 & 13.0 \\
\hline \multicolumn{7}{|c|}{ Profile 4 - Latossolo Amarelo Distrófico típico(Oxisol) } \\
\hline A & 384 & 335 & 35 & 1.9 & 1.8 & 15.0 \\
\hline$A B$ & 395 & 362 & 38 & 1.9 & 1.7 & 15.0 \\
\hline BA & 405 & 382 & 35 & 1.8 & 1.7 & 17.1 \\
\hline Bw1 & 408 & 416 & 39 & 1.7 & 1.6 & 16.7 \\
\hline Bw2 & 420 & 438 & 36 & 1.6 & 1.5 & 19.1 \\
\hline Bw3 & 418 & 435 & 35 & 1.6 & 1.6 & 19.5 \\
\hline Bw4 & 388 & 392 & 39 & 1.7 & 1.6 & 15.8 \\
\hline Bw5 & 387 & 380 & 34 & 1.7 & 1.6 & 17.5 \\
\hline \multicolumn{7}{|c|}{ Profile 5 - Cambissolo Háplico Distrófico latossólico antrópico(Cambisol } \\
\hline Au1 & 75 & 62 & 13 & 2.1 & 1.8 & 7.5 \\
\hline Au2 & 80 & 65 & 6 & 2.1 & 2.0 & 17.0 \\
\hline Au3 & 92 & 78 & 9 & 2.0 & 1.9 & 13.6 \\
\hline$A B$ & 88 & 75 & 13 & 2.0 & 1.8 & 9.1 \\
\hline BA & 104 & 88 & 9 & 2.0 & 1.9 & 15.4 \\
\hline Bi1 & 110 & 95 & 12 & 2.0 & 1.8 & 12.4 \\
\hline $\mathrm{Bi} 2$ & 112 & 92 & 9 & 2.1 & 1.9 & 16.0 \\
\hline $\mathrm{Bi} 3$ & 122 & 98 & 13 & 2.1 & 2.0 & 11.8 \\
\hline \multicolumn{7}{|c|}{ Profile 6 - Cambissolo Húmico Distrófico antrópico(Cambisol) } \\
\hline Au1 & 84 & 70 & 12 & 2.0 & 1.8 & 9.2 \\
\hline Au2 & 98 & 84 & 12 & 2.0 & 1.8 & 11.0 \\
\hline Au3 & 112 & 97 & 9 & 2.0 & 1.9 & 16.9 \\
\hline$A B$ & 110 & 88 & 9 & 2.1 & 2.0 & 15.4 \\
\hline $\mathrm{Bi1}$ & 120 & 98 & 13 & 2.1 & 1.9 & 11.8 \\
\hline $\mathrm{Bi} 2$ & 123 & 101 & 10 & 2.1 & 1.9 & 15.9 \\
\hline
\end{tabular}

horizons, reaching up to $355 \mathrm{mg} \mathrm{kg}^{-1}$ in the Au1 horizon of $\mathrm{P} 5$. Moreover, in P3, P contents were higher than $100 \mathrm{mg} \mathrm{kg}^{-1}$ in all horizons, at a depth greater than $200 \mathrm{~cm}$; these values come from the bone remains of both animal and human origin, which are also a source of calcium (Mattar et al., 2014; Barbosa et al., 2020).

In the non-anthropogenic soils (P1, P2, P4), the acidic pH was present in almost all horizons, ranging from 4.33 to 5.47 . This higher acidity, reflected directly in the exchangeable $\mathrm{Al}^{3+}$ levels, considered as toxic in all horizons of these profiles, ranging from 0.4 to $2.8 \mathrm{cmolc} \mathrm{kg}^{-1}$. Additionally, $\mathrm{Ca}^{2+}$ and $\mathrm{Mg}^{2+}$ contents are very low, ranging between 0.1 and $0.6 \mathrm{cmolc} \mathrm{kg}^{-1}$, and 0.1 and $0.4 \mathrm{cmolc} \mathrm{kg}^{-1}$, respectively; thus reflecting in $\mathrm{S}$ value lower than $1.0 \mathrm{cmolc} \mathrm{kg}^{-1}$ and base saturation lower than $21 \%$ in all horizons. This is directly related to intense leaching of soils under tropical climate conditions in the Amazon (Freitas et al., 2013). P contents in these soils are considered very low, ranging between 2 and $6 \mathrm{mg} \mathrm{kg}^{-1}$, which were explained by the high acidity that favors the fixation of phosphate on the surface of the oxides (Corrêa et al., 2011).

Only in P1 the TOC contents were higher than $20 \mathrm{~g} \mathrm{~kg}^{-1}$, which may be associated with drainage restriction, where the anaerobic conditions predominance favors the accumulation of organic matter. Despite being inserted in a floodplain environment, which favors the addition of bases, the P1 profile has a very low $\mathrm{V} \%$ value and strongly acid $\mathrm{pH}$, a pattern that differs from the floodplain soils of the Solimões Basin (Guimarães et al., 2013). This characteristic may be related to the predominance of source material from acidic nature in the region and the deposition of more weathered sediments along the slopes of the Tapajós River in the lower Amazon (IBGE, 2008).

The pedogenetic oxide content indicate a high rate of weathering (Santos et al., 2018), with the $\mathrm{Al}_{2} \mathrm{O}_{3}$ values higher than the $\mathrm{SiO}_{2}$, thus signalizing a greater solubilization and silica removal, a pattern verified in almost all subsurface horizons of profiles P2, P3 and P4 (Table 4). In these horizons, the ki index $\left(\mathrm{SiO}_{2} / \mathrm{Al}_{2} \mathrm{O}_{3}\right)$ ranged from 1.1 to 1.8 , showing an intense removal of silica. Associated with this pattern are the low activity values of the clay fraction in these profiles, which is directly related to the climate conditions in the Amazonian environment, where high rainfall provides greater removal of silica (Novaes Filho et al., 2012). In P5 and P6, although the $\mathrm{ki}$ index is also considered as low, the values ranged from 2.0 to 2.1 and associated with the higher clay activity values observed, suggesting lesser weathering.

In all studied soils, the $\mathrm{Fe}_{2} \mathrm{O}_{3}$ content were considered as very low, ranging from 3.0 to $39.0 \mathrm{~g} \mathrm{~kg}^{-1}$, classified as hypopherric (Santos et al., 2018b). Santos et al. (2013) also observed a similar pattern for $\mathrm{Fe}_{2} \mathrm{O}_{3}$ content in Amazonian soils, relating the low contents directly to the nature of the source material. Furthermore, a low $\mathrm{Fe}_{2} \mathrm{O}_{3}$ content contributes to low $\mathrm{kr}$ values $\left(\left(\mathrm{SiO}_{2} /\left(\mathrm{Al}_{2} \mathrm{O}_{3}+\mathrm{Fe}_{2} \mathrm{O}_{3}\right)\right)\right.$ and for the very high values of the $\mathrm{Al}_{2} \mathrm{O}_{3} / \mathrm{Fe}_{2} \mathrm{O}_{3}$ ratio, which ranged from 7.5 to 135.0.

According to the SiBCS (Santos et al., 2018b), the P1 profile has a humic $A$ surface diagnostic horizon, a glei subsurface, and incipient $B$ horizon coinciding in the same section, due to the predominance of grayish colors with high value and low chroma and the incipient development of structure with aggregation. It has clay of low activity and base saturation of less than $50 \%$, thus classified as a Melanic Gleissolous Tb Dystrophic cambisolic.

Profiles P2, P3 and P4 have subsurface diagnostic horizon $B$, due to their thickness above $50 \mathrm{~cm}$, clay activity $<17$ $\mathrm{cmolc} \mathrm{kg}^{-1}$ and ki index $<2.2$. In addition, they have yellowish hue (10YR) and base saturation less than $50 \%$. In P2, the $\mathrm{B} / \mathrm{A}$ ratio was 1.58 , which is insufficient to characterize the textural gradient. In $\mathrm{P} 3$, the superficial diagnostic horizon was classified as anthropic A, due to its thickness $>20 \mathrm{~cm}$, presence of ceramic artifacts and bone remains, and high 
levels of available P, hence classified as "Latossolo Amarelo Distrófico antrópico" (dystrophic yellow Oxisol). Profile P4, for not having any differential characteristic for the subgroup level, was classified as Latossolo Amarelo Distrófico antrópico (dystrophic anthropic yellow Oxisol).

Profile P5 has a subsurface horizon $>50 \mathrm{~cm}$ thick, gradual transition between $B$ subhorizons and a ki index $<2.2$; however, the clay activity is slightly higher than $17 \mathrm{cmolc} \mathrm{kg}^{-1}$, classifying it as incipient $B$, but with its morphological characteristics similar to those of the latosolic B. It has low base saturation and anthropic A diagnostic horizon, suggesting the creation of the subgroup "antrópico" (anthropic) for the class of "Cambissolos Háplicos" (haplic Cambisols) in the BSCS (Santos et al., 2018b). Associating these attributes thus classifies the profile as a "Cambissolo Háplico Tb Distrófico latossólico antrópico" (anthropic latsolic dystrophic Tb haplic Cambisol).

Profile P6 has an incipient subsurface diagnostic horizon $\mathrm{B}$, with clay of low activity, but higher than $17 \mathrm{cmolc} \mathrm{kg}$ 1 , presence of easily altered primary minerals, and base saturation $<50 \%$. The surface horizon of this profile has enough thickness, structure and TOC content to characterize the humic A horizon; however, $\mathrm{P}$ contents and the presence of ceramic fragments and bone remains show evidence of anthropic activity. Therefore, the suggestion is the creation of the subgroup "antrópico" (anthropic) for the "Cambissolos Húmicos" (Humic Cambisols) in the BSCS. That way, the association of these attributes classifies the profile as a "Cambissolo Húmico Distrófico antrópico" (anthropic Humic Distrophic Cambisol).

\section{Conclusions}

Anthropic activity of pre-Columbian people in western Pará state is the main factor responsible for the occurrence of soils with thick superficial horizons with high levels of organic carbon, $\mathrm{Ca}^{2+}, \mathrm{Mg}^{2+}$ and $\mathrm{P}$, different from the pattern found for non-antropized soils.

The great variability found in the soil texture of western Pará is closely related to the occurrence of sedimentary rocks of a clastic nature of different Granulometry, such as sandstones, argillites and conglomerates.

Floodplain "Gleisolos" (Entisols) of the lower Amazon are highly weathered, dystrophic and with low activity clays, differing from the pattern in floodplain soils from the Solimões River basin.

By observing anthropic superficial diagnostic horizon A in profiles of "Cambissolos Húmicos" (Humic Cambisols), the suggestion is to create the "antrópico" (anthropic) subgroup for these soil classes in the Brazilian Soil Classification System.

\section{Compliance with Ethical Standards}

Funding: This study was financed by the Brazilian Federal Agency for Support and Evaluation of Graduate Education (CAPES, finance code 001) and Fundação Carlos Chagas Filho de Amparo à Pesquisa do Estado do Rio de Janeiro (Faperj).
Conflict of interest: The authors declare no conflict of interest.

Author contribution: Conceptualization: CRPJ, MGP, IMSR; Data curation: CRPJ, MGP, IMSR; Formal analysis: APA, MAS, LASRP, OAQS; Funding acquisition: CRPJ, MGP, IMSR; Investigation: MGP, IMSR; Methodology: CRPJ, MGP; Project administration: MGP, IMSR; Resources: MGP, IMSR; Supervision: MGP, IMSR; Validation: MGP, IMSR; Visualization: MGP, IMSR; Writing - original draft: CRPJ, MGP, IMSR; Writing - review \& editing: CRPJ, MGP, IMSR.

\section{Literature Cited}

Aquino, R. E.; Campos, M. C. C.; Marques Júnior, J.; Oliveira, I. A.; Mantovaneli, B. C.; Soares, M. D. R. Geoestatística na avaliação dos atributos físicos em Latossolo sob floresta nativa e pastagem na região de Manicoré, Amazonas. Revista Brasileira de Ciência do Solo, v. 38, n.2, p.397-406, 2014. https://doi.org/10.1590/ S0100-06832014000200004.

Araújo Filho, J. C.; Barbosa Neto, M. V.; Silva, C. B.; Araújo, M. S. B.; Menezes, J. B. Levantamento semidetalhado dos solos da Bacia Hidrográfica do Rio Natuba, Pernambuco. Revista Brasileira de Geografia Física, v. 6, n.3, p.384-397, 2013. https://periodicos. ufpe.br/revistas/rbgfe/article/view/233033/26960. 29 Mar. 2020.

Barbosa, J. Z.; Motta, A. C. V.; Corrêa, R. S.; Muniz, A. W.; Martins, G. C.; Silva, L. D. C. R.; Teixeira, W. G.; Young, S. D.; Broadley, M. R. Elemental signatures of an Amazonian Dark Earth as result of its formation process. Geoderma, v. 361, e114085, 2020. https:// doi.org/10.1016/j.geoderma.2019.114085.

Batistão, A. C.; Holthusen, D.; Reichert, J. M.; dos Santos, L. A. C.; Campos, M. C. C. Resilience and microstructural resistance of Archaeological Dark Earths with different soil organic carbon contents in Western Amazonia, Brazil. Geoderma, v. 363, e114130, 2020. https://doi.org/10.1016/j. geoderma.2019.114130.

Corrêa, R. M.; Nascimento, C. W. A.; Rocha, A. T. Adsorção de fósforo em dez solos do Estado de Pernambuco e suas relações com parâmetros físicos e químicos. Acta Scientiarum. Agronomy, v. 33, n. 1, p.153-159, 2011. https://doi.org/10.4025/actasciagron. v33i1.3129.

Farias, S. C. C.; Silva Júnior, M. L.; Ruivo, M. L. P.; Rodrigues, P. G.; Melo, V. S.; Costa, A. R.; Sousa Júnior, J. C. Phosphorus Forms in Ultisol Submitted to Burning and Trituration of Vegetation in Eastern Amazon. Revista Brasileira de Ciência do Solo, v. 40, e150198, 2016. https://doi.org/10.1590/18069657rb cs20150198.

Fisch, G.; Marengo, J. A.; Nobre, C. A. Uma revisão geral sobre o clima da Amazônia. Acta Amazonica, v. 28, n.2, p. 101-126, 1998. https://doi.org/10.1590/1809-43921998282126.

Freitas, I. C.; Santos, F. C. V.; Custódio Filho, R. O.; Correchel, V.; Silva, R. B. Agroecossistemas de produção familiar da Amazônia e seus impactos nos atributos do solo. Revista Brasileira de Engenharia Agrícola e Ambiental, v. 17, n.12, p. 1310-1317, 2013. https://doi. org/10.1590/s1415-43662013001200009. 
Guimarães, S. T.; Lima, H. N.; Teixeira, W. G.; Neves Junior, A. F.; Silva, F. W. R.; Macedo, R. S.; Sousa, K. W. Caracterização e classificação de Gleissolos da várzea do Rio Solimões (Manacapurue Iranduba), Amazonas, Brasil. Revista Brasileira de Ciência do Solo, v. 37, n.2, p. 317-326, 2013. https://doi.org/10.1590/S010006832013000200003.

Instituto Brasileiro de Geografia e Estatística - IBGE. Estado do Pará. Geomorfologia. Rio de Janeiro: IBGE, 2008. 1p.

Instituto Brasileiro de Geografia e Estatística - IBGE. Manual técnico de pedologia. Rio de Janeiro: IBGE, 2015. 425 p.

Kämpf, N.; Curi, N. Formação e evolução do solo (pedogênese). In: Ker, J. C.; Shaefer, C. E. G. R; Vidal-Torrado, P. (Orgs.). Pedologia: fundamentos. Viçosa: Sociedade Brasileira de Ciência do Solo, 2012. p. 207-302.

Mattar, E. P. L.; Frade Júnior, E. F.; Oliveira, E. Caracterização físicoquímica de cinza de osso bovino para avaliação do seu potencial uso agrícola. Pesquisa Agropecuária Tropical, v. 44, n. 1, p. 65-70, 2014. https://doi.org/10.1590/S1983-40632014000100003.

Meireles, H. T.; Marques Júnior, J.; Campos, M. C. C.; Pereira, G. T. Relação solo-paisagem em topossequência de origem basáltica. Pesquisa Agropecuária Tropical, v. 42, n. 2, p. 129-136, 2012. https://doi.org/10.1590/S1983-40632012000200001.

Mendes, A. C.; Truckenbrod, W.; Nogueira, A. C. R. Análise faciológica da Formação Alter do Chão (Cretáceo, Bacia do Amazonas), próximo à cidade de Óbidos, Pará, Brasil. Revista Brasileira de Geociências, v. 42, n. 1, p. 39-57, 2012. http://ppegeo.igc.usp.br/ index.php/rbg/article/view/7873/7300. 11 Apr. 2020.

Novaes Filho, J. P.; Couto, E. G.; Rodrigues, L. C. M.; Chig, L. A.; Johnson, M. S. Indicativos de descontinuidade litológica de regolitos derivados de granitos em uma microbacia sob floresta Amazônica, em Juruena-MT. Revista Brasileira de Ciência do Solo, v. 36, n. 2, p. 317-324,2012. https://doi.org/10.1590/ S0100-06832012000200001.

Rabot, E.; Wiesmeir, M.; Schlüter, S.; Vogel, H. J. Soil structure as an indicator of soil functions: a review. Geoderma, v. 314, p. 122137, 2018. https://doi.org/10.1016/j.geoderma.2017.11.009.

Santos, H. G.; Jacomine, P. K. T.; Anjos, L. H. C.; Oliveira, V. A.; Lumbreras, J. F.; Coelho, M. R.; Almeida, J. A.; Araújo Filho, J. C.; Oliveira, J. B.; Cunha, T. J. F. Sistema Brasileiro de Classificação de Solos. 5. ed. Brasília: Embrapa, 2018b. 356 p.
Santos, L. A. C.; Araujo, J. K. S.; Sousa Júnior, V. S.; Campos, M. C. C.; Corrêa, M. M.; Sousa, R. A. S. Pedogenesis in an Archaeological Dark Earth-Mulatto Earth Catena over Volcanic Rocks in Western Amazonia, Brazil. Revista Brasileira de Ciência do Solo, v. 42, e0170359, 2018a. https://doi.org/10.1590/18069657rb cs20170359.

Santos, L. A. C.; Campos, M. C. C.; Aquino, R. E. D.; Bergamin, A. C.; Silva, D. M. P. D.; Marques Junior, J.; França, A. B. C. Caracterização de terras pretas arqueológicas no sul do estado do Amazonas. Revista Brasileira de Ciência do Solo, v. 37, n. 4, p. 825836, 2013. https://doi.org/10.1590/S0100-06832013000400001.

Santos, R. D.; Santos, H. G.; Ker, J. C.; Anjos, L. H. C.; Shimizu, S. H. Manual de descrição e coleta de solo no campo. 7. ed. Viçosa: SBCS, 2015. 100 p.

Silva Junior, C. A.; Boechat, C. L.; Carvalho, L. A. Atributos químicos do solo sob conversão de Floresta Amazônica para diferentes sistemas na Região Norte do Pará, Brasil. Bioscience Journal, v. 28, n.4, p. 566-572, 2012. http://www.seer.ufu.br/index.php/ biosciencejournal/article/view/13640/9746. 11 Abr. 2020.

Sousa, J. J. L. L.; Fontes, M. P. F.; Gilkes, R.; Costa, L. M.; Oliveira, T. S. Geochemical signature of Amazonian tropical rainforest soils. Revista Brasileira de Ciência do Solo, v. 42, e0170192, 2018. http://doi.org/10.1590/18069657rbcs20170192.

Teixeira, P. C.; Donagemma, G. K.; Fontana, A.; Teixeira, W. G. Manual de métodos de análise de solo. 3.ed. Brasília: Embrapa, 2017. $575 \mathrm{p}$.

Vale Júnior J. F.; Sousa, M. I. L.; Nascimento, P. P. R. R.; Cruz, D. L. S. Solos da Amazônia: etnopedologia e desenvolvimento sustentável. Revista Agro@mbiente, v. 5, n. 2, p. 158-165, 2011. https://doi.org/10.18227/1982-8470ragro.v5i2.562.

Yeomans, J. C.; Bremner, J. M. A rapid and precise method for routine determination of organic carbon in soil. Communication in Soil Science Plant Analysis, v. 19, n.13, p. 1467-1476, 1988. https:// doi.org/10.1080/00103628809368027.

Zenero, M. D. O.; Silva, L. F. S.; Castilho, S. C. P.; Vidal, A.; Grimaldi, M.; Cooper, M. Characterization and Classification of Soils under Forest and Pasture in an Agroextractivist Project in Eastern Amazonia. Revista Brasileira de Ciência do Solo, v. 40, e0160165, 2016. https://doi.org/10.1590/18069657rbcs20160165. 